\title{
АСПЕКТИ КОРПОРАТИВНОЇ КУЛЬТУРИ ЗАКЛАДІВ ОХОРОНИ ЗДОРОВ'Я ЗА УМОВ РЕФОРМУВАННЯ ГАЛУЗІ
}

\author{
О. Н. Литвинова ${ }^{1}$, Н. М. Абашник ${ }^{2}$ \\ ${ }^{1}$ Тернопільський національний медичний університет \\ імені І. Я. Горбачевського МОЗ Украӥни \\ ${ }^{2}$ Комунальне некомериійне підприємство \\ Харківської обласної ради “Обласна клінічна лікарня"
}

У статті розглянуто питання корпоративної культури та їі особливостей в закладах охорони здоров’я в період реформування системи охорони здоров’я. Акцентовано на проблемах корпоративної культури в сучасних умовах інформаційного суспільства в закладах охорони здоров’я, порушених різними авторами.

\section{ASPECTS OF CORPORATE CULTURE IN HEALTHCARE INSTITUTIONS UNDER THE CONDITIONS OF INDUSTRY REFORM}

\author{
O. N. Lytvynova ${ }^{1}$, N. M. Abashnyk ${ }^{2}$ \\ ${ }^{1}$ I. Horbachevsky Ternopil National Medical University \\ ${ }^{2}$ Communal Nonprofit Enterprise of Kharkiv Regional Council "Regional Clinical Hospital”
}

The article raises issues of corporate culture and its features in health care facilities on the background of the reform of the health care system. Emphasis is placed on the problems of corporate culture in the modern conditions of the information society in health care facilities, raised by various authors.

Вступ. Базова стратегія закладу охорони здоров'я $\epsilon$ першоосновою формування корпоративної культури, що забезпечує стратегію стабільності та ефективності ії діяльності за умов реформування системи охорони здоров'я.

На сьогодні ефективність закладу охорони здоров'я найчастіше визначається рівнем його корпоративної культури. Тому, за умов реформування системи охорони здоров'я, необхідність ії формування $\epsilon$ невід'ємною складовою ефективної діяльності закладу.

Корпоративна культура ґрунтується на стратегії організації, оскільки найкраще підтримує місію, цілі та стратегію закладу. У закладах охорони здоров'я ці моменти мають свою специфіку, яка пов'язана з різним сприйняттям хвороби медичним персоналом, пацієнтами та їхніми родичами. Саме ця специфіка викликає ряд непорозумінь аж до конфліктів, які на сьогодні так широко висвітлюють засоби масової інформації, та вимагає від персоналу закладів охорони здоров'я навиків диференційованого підходу до (с) О. Н. Литвинова, Н. М. Абашник, 2021 різних категорій учасників відносин у сфері медичної допомоги.

Виходячи із пріоритетної чисельності та ролі медсестри в закладі охорони здоров'я, вона виступає основним генератором корпоративної культури в організації. Саме ці питання і підтверджують актуальність і лягли в основу нашого дослідження, об'єктом якого були елементи корпоративної культури, а предметом - оцінка впливу на корпоративну культуру середнього медичного персоналу.

Метою нашого дослідження було виявити обсяг та рівні впливу медсестри на корпоративну культуру в закладі охорони здоров'я для підвищення ефективності його діяльності.

Тому одним із важливих завдань було вивчення теоретичних засад, сутності та структури корпоративної культури в організаціях та виокремлення складових корпоративної культури в закладі охорони здоров'я як організації.

Основна частина. Стратегічний менеджмент, теорія організації та організаційної поведінки - це 
три наукові напрямки, які у 80-х роках XX ст. почали структурно та змістовно формувати концепцію корпоративної культури. 3 цього часу досліджують у західній економічній літературі корпоративну культуру як одну з ефективних сучасних форм управління [1].

В Україні навіть в останні десятиліття корпоративну культуру не завжди розглядали як сферу, що заслуговує на пильну увагу, особливо це стосується бюджетної сфери. Однак важливість зазначеної проблеми зростає, зокрема внаслідок глобальних змін, коли збут продукції та надання послуг стали значно складнішими за виробництво, поява нової практики управління почала випереджати теорію. У процесі соціально-економічних реформ в Україні корпоративну культуру поступово починають впроваджувати у вітчизняний соціально-економічний простір [1].

Загальноприйняті складові елементи корпоративної культури - це організаційні та ідейні.

До організаційних елементів корпоративної культури найчастіше відносять систему лідерства, норми поведінки, формування робочого процесу, способи вирішення конфліктів, систему комунікацій, корпоративний стиль тощо. Сюди входять ситуації, з якими персонал стикається кожен день: в який час приходити і залишати робоче місце, чи є право відлучатися з робочого місця, як одягатися, як спілкуватися з колегами [2].

До ідейних елементів корпоративної культури належать традиції, особистісні цінності, цінності компанії, вектор розвитку та інші. Наприклад, філософія установи передбачає здоровий спосіб життя, а новий співробітник не любить спорт [3]. Йому і колективу некомфортно один з одним - у них різні цінності.

У міру того, як розвинутий світ переходить від індустріального до інформаційного суспільства, адхократична культура найбільш адекватно реагує на надзвичайно бурхливий світ, який інтенсивно змінюється [4]. Адаптація до зовнішнього середовища, новаторські, випереджуючі час рішення, передбачення майбутнього - це саме те, що приводить до успіху. Медичний заклад працює в напрямку розробок нових методів лікування та нових медичних послуг. Вона не використовує централізовану владу і авторитарні стосунки. Влада переходить від однієї людини до іншої чи від однієї цільової бригади до іншої залежно від проблеми, яка заявляє про себе в даний момент часу [5]. Яскраво виражений акцент на індивідуальності, компетентності, заохоченні ризику та передбаченні майбутнього.
Адхократична культура потрібна в медицині, зокрема для високопрофесійного консультування, підбору нових методів лікування. Наприклад, звернення окремого пацієнта в медичну клініку трактується як незалежна програма і на задоволення його вимог орієнтується тимчасово організована бригада, яка зразу після виконання програми може розформуватися. За творчість і новаторство в розв'язанні медичних проблем чи наданні медичних послуг персонал отримує великі нагороди. Працівники готові жертвувати собою та йти на ризик. Ефективне лідерство полягає в умінні передбачати, йти на ризик, експериментувати, проявляти новаторство та бути готовим до змін і йти на зустріч новим викликам часу та зовнішнього середовища [6]. Успіх означає надання унікальних ефективних медичних послуг.

Ще років 10-15 тому роботодавці були упевнені, що середня зарплатня, гарні умови праці та своєчасна оплата - гарантія залучення співробітників до робочого процесу. В системі охорони здоров'я така ситуація була ще гіршою - головні лікарі знали, що з медичною освітою людина більше нікуди не влаштується і особливо не переймалися ні умовами праці, ні своєчасною виплатою зарплати, відносились абияк, бо «куди вони дінуться...».

Зараз же зовсім інші реалії, більшість працівників - покоління Z, у яких інший світогляд та життєва позиція [7]. Люди цього покоління народжуються 3 підприємницьким талантом. Вони хочуть від роботодавця партнерських відносин, щоб він був не просто керівником, а наставником, ментором. Їм важливий розвиток у компанії та допомога в реалізації своїх професійних та особистих цілей.

У зв'язку з такими змінами все більше компаній впроваджують системи бонусів, лояльніше ставляться до побажань співробітників, реагують на їхні потреби. Хвиля плинності кадрів у системі охорони здоров'я спонукає генеральних директорів закладів охорони здоров'я повернутися лицем до медичного персоналу та його інтересів.

Залучення співробітників більшою мірою залежить від керівників компанії. Навіть якщо в організації найкращі умови праці, сучасний офіс, нові програми розвитку, але відсутня віра топ-менеджменту в конкретного працівника, то сподіватися на його професійний розвиток не варто.

За даними Gallup, залучення співробітників на $70 \%$ залежить від керівництва. За їх даними, ми бачимо, що у незалучених співробітників менший відсоток 
лояльності. І навпаки, у залучених працівників більший відсоток лояльності щодо компанії. Тому головний акцент у підвищенні залучення персоналу ставиться саме на розвиток керівника та його взаємодію з працівниками [8].

Паралельно із залученням персоналу в корпоративній культурі значне місце посідає підвищення значущості співробітників. Важливим чинником підвищення ролі персоналу в сучасному виробництві $\epsilon$ принципові зміни в змісті праці, викликані застосуванням нових технологій і методів виробничої діяльності.

На конкурентному ринку медичної допомоги саме корпоративна культура, індивідуальна аура закладу охорони здоров'я можуть стати вирішальними аргументами для пацієнта при виборі клініки та лікаря [9].

Культура організації закладу охорони здоров'я впливає на представлення основних цінностей в організаційній структурі, системі управління, кадровій політиці.

Також розуміння організаційної культури може бути розширене, якщо ознайомитися з тим, як побудована система кар'єри в закладі охорони здоров'я і які критерії слугують для просування працівників. У разі, якщо в організації працівники швидко будують кар'єру, і не завжди за результатами індивідуальних досягнень, можна припустити, що існує слабка організаційна культура [10]. Варто відзначити, що у закладі охорони здоров'я кар'єрне зростання обмежене посадами, освітою та спеціалізацією.

Корпоративна культура закладу охорони здоров'я виконує свої функції. До найважливіших можна віднести внутрішню інтеграцію закладу в єдине ціле, що підвищує рівень організованості та керованості, формування певного іміджу закладу охорони здоров'я та його адаптації до змін в економіці за умов реформування. Вона допомагає зрозуміти основні уявлення, цінності, очікування та норми, що поділяються більшістю співробітників компанії; звернути увагу на традиції, правила та міфи, що існують у компанії; передбачити ставлення співробітників до типових ситуацій: адаптація нового співробітника, наявні стереотипи вирішення конфліктних ситуацій, стереотипи ставлення до керівництва, успіхів чи невдач, стереотипи щодо якості роботи та обслуговування пацієнтів тощо.

Заклади охорони здоров'я створюються підприємствами, установами та організаціями з різними формами власності, а також приватними особами при наявності необхідної матеріально-технічної бази і кваліфікованих фахівців. Порядок і умови створення закладів охорони здоров'я, державної реєстрації та акредитації цих закладів, а також порядок ліцензування медичної та фармацевтичної практики визначаються актами законодавства України. Але навіть за таких умов, як переконує Р. Гелегер «сила впливу основних культурних цінностей величезна, і вони можуть бути змінені лише в результаті спільної згоди та великих зусиль. Вони зберігаються і відтворюються, навіть якщо компанії доростають до міжнародних масштабів, коли на них працюють тисячі людей, які проживають в усьому світі. Саме такі ключові культурні цінності і $є$ тим, що можна назвати «душею організації» [11].

Зміцнення згуртованості медичних працівників довкола мети професійної діяльності, формування відповідної корпоративної культури в закладах охорони здоров'я та злагоджена, чітка робота всього колективу $\epsilon$ запорукою успіхів у відновленні здоров'я людини.

Про наявність офіційної корпоративної культури можна говорити, якщо прописані організаційні цінності, правила і норми. Важливо розуміти, що у будь-якому випадку в закладі охорони здоров'я існує та чи інша культура, навіть якщо вона ніде не прописана. Відповідні правила створюють для того, щоб документально оформити вже сформовану культуру, привнести в неї елементи ідеальної моделі закладу охорони здоров'я.

Для закладів охорони здоров'я характерна відсутність яскраво вираженого типу корпоративної культури, адже медичні працівники не можуть точно оцінити культуру. Можливо це пов'язано з незнанням критеріїв оцінювання та зі складною системою міжособистісних стосунків у медичній організації. Більшою мірою проявляється ієрархічна культура, кланова і адхократична - значно меншою мірою відповідно.

На думку медичного персоналу, найбільш корисні адхократична та кланова культури. Таким чином, сучасні тенденції розвитку медичної організації потребують формування культури інноваційного типу. Працівники також мріють про рівноправні, теплі стосунки між підлеглими та керівниками, тобто бажають, щоб розвивалася в організації і кланова культура. Також має попит і ринкова культура. Формування корпоративної культури потребує врахування послідовності її розвитку [12].

Починати необхідно з формування і сприймання місії (призначення) та філософії медичної організації, 
зі створення взірців керівників, які втілюють найкращі цінності та норми поведінки, потім потрібно переходити до створення і втілення змін у поведінці підлеглих. Важливо також виявляти рівень професіоналізму та мотивації медичних працівників, психологічний клімат, корпоративні традиції та оцінку домінуючої культури в організації.

Успіх у досягненні результатів діяльності закладу охорони здоров'я багато в чому залежить від урахування системи цінностей, можливості втілення інновацій в сфері медицини, відданості спільній справі, бачення перспектив розвитку організації, рівноправності взаємин між медичним персоналом та пацієнтами, стилів управління, способів мислення та підходів до розв'язання проблем, від адаптації та внутрішньої інтеграції людей, від уміння виживати в складному соціально-економічному середовищі, тобто від корпоративної культури [13].

Високий рівень корпоративної культури $є$ важливим стратегічним чинником, який мобілізує всі структурні ланки медичних установ та їх працівників на досягнення поставлених цілей в рамках задекларованої місії організації. Тому на сьогодні формування корпоративної культури є важливим чинником досягнення успіху в організаціях.

Корпоративна культура закладу охорони здоров'я визначає шлях розвитку в сфері управління персоналом.

\section{СПИСОК ЛІТЕРАТУРИ}

1. Щербак Н. В. Роль корпоративної культури у підвищенні рівня професійної компетентності державних службовців та посадових осіб місцевого самоврядування в умовах реформування державного управління [Електронний ресурс] / Н. В. Щербак // Актуальні проблеми державного управління. - 2016. - № 1. - С. 166-172. Режим доступу : file:///C:/Users/OH/Desktop/5.10/195\% D 0\%A2 \% D 0 \% B \% D 0 \% BA \% D 1 \% $81 \%$ D $1 \% 82 \% 20$ \% D $1 \% 81$ \% D 1 \% 82 \% D $0 \%$ B $0 \%$ D $1 \% 82 \%$ D $1 \% 82$ \%D1\%96-503-1-10-20201117.pdf.

2. Сова А. В. Роль керівника в формуванні організаційної культури [Електронний ресурс] / А. В. Сова // Ефективна економіка. - 2015. - № 6. - Режим доступу : http://www. economy.nayka.com.ua/?op=1\&z=4471.

3. Леонова О. Створення корпоративної культури [Електронний ресурс] / О. Леонова. - Режим доступу : https://hurma.work/blog/stvorennya-korporativno\%D1\%97kulturi/.
Висновки. Модернізація культури управління закладом охорони здоров'я передбачає необхідність визначення соціально-культурологічних протиріч формальної та неформальної систем управління. У контексті реалізації даного етапу можна зробити висновок про те, що культура управління сучасних медичних організацій характеризується неприйнятно жорсткою централізацією і надмірною регламентацією управлінської взаємодії, пов'язаними з наданням медичних послуг.

Пацієнти вважають за необхідне брати активну участь в деяких управлінських процесах медичної організації: брати участь у реалізації функції управлінського контролю; здійснювати спільно з лікарем розробку програм надання медичних послуг; приймати самостійні управлінські рішення щодо вибору оптимальної програми дій з надання медичної послуги.

Існуючі умови культурних управлінських комунікацій викликають роздратування пацієнтів, які переконані не тільки в необхідності змін, але і в удосконаленні внутрішньоорганізаційної культури управлінських комунікацій, пропонують організаційно-нормативну і культурну перебудову системи управління охорони здоров'я в цілому і окремих медичних організацій зокрема.

Подальші наші дослідження будуть присвячені поглибленому вивченню корпоративної культури в закладах охорони здоров'я з акцентом на роль медсестри саме у формуванні цієї культури.

4. Баюра Д. О. Методологічні підходи до формування корпоративної культури у системі корпоративного управління [Електронний ресурс] / Д. О. Баюра // Науковий вісник ЧДІЕУ. - 2011. - № 4 (12). - Режим доступу : http:// www.nvisnik.geci.cn.ua/pdf/2011/nv_4(12)/024-028.pdf.

5. Управління персоналом в органах публічної влади : навч. посіб. / С. М. Серьогін, Є. І. Бородін, К. В. Комарова та ін. - Дніпро : ДРІДУ НАДУ, 2019. - 200 с.

6. Лідерство та ефективне управління : Проєкт ЄС Прямуємо разом [Електронний ресурс]. - Режим доступу : https://eduhub.in.ua/files/159610508441829.pdf.

7. Воронкова В. Г. Управління людськими ресурсами: філософські засади [Електронний ресурс] : навч. посіб. / В. Г. Воронкова. - Режим доступу : http: // pidruchniki.ws / 12210605 / menedzhment / rol_korporativnoyi_kulturi_ upravlinni_lyudskimi_resursami.

8. Маркасьян П. Дослідження залученості персоналу або як «увімкнути» своїх співробітників по максимуму 
[Електронний ресурс] / П. Маркасьян. - Режим доступу : https://hurma.work/blog/doslidzhennya-zaluchenostipersonalu-abo-yak-uvimknuti-svo\%D1\%97h-spivrobitnikivpo-maksimumu/.

9. Дашкова Е. С. Особенности корпоративной культуры в организациях системы здравоохранения / Е. С. Дашкова // Вестник ВГУ. - 2014. - № 1. - С. 68-72. - (Серия «Экономика и управление»).

10. Зеркаль А. В. Перспективи підвищення якості управління персоналом крізь призму корпоративної культури / А. В. Зеркаль // Інвестиції: практика та досвід. - 2015. № 24. - C. 44-48.
11. Гелегер Р. Душа организации. Как создать успешную корпоративную культуру / Р. Гелегер. - М. : Добрая книга, 2006. - 352 с.

12. Шулдик А. В. Типи корпоративної культури в медичних організаціях [Електронний ресурс] / А. В. Шулдик. - Режим доступу : http://dspace.udpu.edu.ua/jspui/ bitstream/6789/9852/1/KROK.pdf.

13. Сингаевская И. В. Позитивная корпоративная культура как фактор мотивации персонала / И. В. Сингаевская // Предпринимательство в Беларуси: опит становления и перспективы развития : материалы XIII Междунар. научн.-практ. конф., 7 апреля 2016 г. Минск, 2016. - С. 83-88.

Отримано 18.02.21 